\title{
Pengembangan Modul Seni Musik Berbasis Experiential Learning untuk Meningkatkan Kemampuan Bermain Musik pada Mata Pelajaran Seni Budaya dan Prakarya Siswa Sekolah Dasar
}

\author{
Jaka Nugraha ${ }^{1}$, Santoso $^{2}$, Murtono $^{3}$ \\ ${ }^{1,2,3}$ Program Studi pendidikan Dasar, Universitas Muria Kudus \\ e-mail: jaka.nugraha0501@gmail.com
}

\begin{abstract}
ABSTRAK. The objectives of this study were (1) to analyze the needs of-based music modules experiential learning to improve the ability to play music in elementary school students, (2) to analyze the feasibility of the-based music art module module experiential learning to improve the ability to play music in elementary school students, (3) ) to analyze the effectiveness of the music art module based on experiential learning to improve the ability to play music in elementary school students. This research uses Research and Depelopment research methods referring to the 10 stages of Borg and Gall. Data collection used is the technique of observation, interviews, and performance of ability to play music. The analysis used in this research is quantitative and qualitative analysis, including the practice of musical instruments, learning observations, and validation of the musical arts module product. The product analysis of the musical arts module based on experiential learning to improve cultural arts and crafts in elementary schools includes 6 stages. Sources of data in this study were teachers and students of class VI SDN Magung 03 and SDN 04 Nagreg. The results of the development of the musical arts module based on experiential learning contain the need for a special module which includes basic learning and the stages of learning in detail, therefore the development of a music art module based on experiential learning is made. After being validated by the validator, it gets a score of 87.5 with category valid. Then thebased music art module is experiential learning applied to the experimental class and the calculation results using the test are obtained sig 5\%, meaning that there is an increase in the ability to play music using the-based music art module experiential learning then the $\mathrm{N}$-gain is 0.4 in the moderate category. The effectiveness test in this study was carried out by comparing the performance results of the student's ability to play music in the control class and the experimental class. It is found that tcount is 6.9. From the results of this study, it can be concluded that the musical arts module based on experiential learning can be used in learning cultural arts and crafts in high classes. Hopefully it can inspire teachers to innovate in other learning.
\end{abstract}

Kata kunci: Development, learning module, ability to play music, experiential learning

\section{PENDAHULUAN}

Proses pembelajaran di sekolah dasar merupakan suatu pondasi awal dalam membentuk karakter anak kedepan,salah satu nya belajar tentang seni dalam sebuah mata pelajaran seni budaya dan prakarya.Ketika anak belajar apa itu seni dan bagaimana mengimplementasikan seni terhadap kesehariannya sangat baik untuk perkembangan psikologis anak artinya seni dapat membentuk satu kepribadian anak yang baik. Pendidikan musik merupakan sesuatu yang sangat penting bagi perkembangan psikologis anak. Musik memiliki manfaat yang begitu banyak terhadap perkembangan psikologis anak juga terhadap pembentukan suatu karakter dalam lingkungan sosialnya artinya dengan belajar music anak dapat memiliki makna dari nilai estetik dari musik terhadap pertumbuhan dan perkembangan mentalnya Ainoer Roffiq (2017). 
Keadaan pembelajaran seni khususnya pada seni musik sangat tidak begitu diperhatikan padahal seni music sangat penting terhadap berbagai pembentukan karakter serta perkembangan psikoligis anak pada masanya,anak dapat memiliki kemampuan yang terus diasah dari sejak dini dan anak dapat mengetahui siapa dirinya dengan potensi yang dimilikinya. Musik memberikan suatu nilai estetik pada anak karena potensi anak itu unik juga berbeda-beda ketika anak belajar music anak akan menjadi karakter dirinya sendiri,hal ini dapat dikombinasikan dengan suatu pengemasan pembelajaran melalui sebuah media modul yang dikombinasikan melalui experiential learning artinya anak akan belajar music secara langsung dengan pengalaman apa yang ia serap sebagai satu kesatuan makna. Untuk itu musik sangat wajib diberikan untuk anak usia sekolah dasar karena music memberikan keunikan tersendiri kepada anak,maka dari itu perlu adanya kemampuan khsusus dari guru untuk melakukan pengemabngan diri memahami makna dalam pembelajaran music yang sangat baik diberikan terhadap anak.

Permasalahan dilapangan yang banyak ditemui adalah guru tidak mampu memberikan pembelajaran musik karena tidak memiliki kemampuan khusus akibatnya pendidikan music di sekolah dasar cenderung kurang bahkan mati sehingga kreativitas dan potensi anak tentang seni menjadi kurang terasah. Menurut Lia Mareza (2017) Pembelajaran seni budaya dan prakarya disekolah dasar adalah satu pelajaran yang berisi tentang pengetahuan dan pembelajaran tentang sei dan kebudayaan khas indonesia. Kemudian Menurut Zain dalam Yusdi (2011: 10) berpendapat kemampuan adalah satu hal sesuatu keahlian terhadap sesuatu hal yang dilakukan terus menerus hingga menjadi suatu hal yang terampil didalam suatu bidang tertentu. Kemampuan bermain Musik adalah Suatu tingkat daya kecerdasan dan berupa keterampilan anak dalam hal kemampuan sebagai suatu kecerdasan motorik dan menuangkannya pada suatu permainan alat musik yang menjadi salah satu poin penting bagi perkembangan psikoligi anak. Music memberikan suatu karakter estetik yang dapat membuat peserta didik tumbuh perkembangan psikologisnya,karena potensi setiap anak itu berbeda tentunya musik membentuk karakter anak yang memiliki daya kemandirian dan kepekaan terhadap lingkungan sosialnya menjadi baik Ananda Khairana Sukandar (2020).Kemdudian menurut Elindra Yeti (2017) kemampuan bermain musik bermanfaat terhadap perkembangan yang ada pada diri peserta didik selanjutnya musik memiliki nilai estetik yang akan membentuk karakter-karakter baik untuk anak salah satunya adalah rasa percaya diri,manidir dan mampu mengembangkan mental pkepekaan anak terhadap lingkungannya

Model experiential learning adalah suatu model pembelajaran yang dikemas dengan mengedepankan pengalaman langsung yang dihadapi oleh peserta didik dengan menyerap makna apa yang didapat ketika pembelajaran artinya pengalaman langsung ini sangat berdampak baik terhadap daya pemahaman peserta didik dalam mengikuti pembelajaran. Aris Abdul Rohman (2019). Pengembangan modul seni musik berbasis experiential learning merupakan sebuah pengembangan yang menekankan pembelajaran dengan berbasis pengalaman siswa yang dituangkan dengan media modul yang dirancang untuk bagaimana siswa dapat aktif didalam pembelajaran dengan berbasis pengalaman langsung yang menitik beratkan pada kemampuan siswa secara praktik sehingga pembelajaran menjadi bermakna.

\section{METODOLOGI}

Metode pada penelitian ini menggunakan R\&D dengan teknik uji coba yaitu quasi eksperimen. pendekatan yang digunakan yaitu kualitatif pada pra pengembangan dan pendekatan kuantitatif pada uji produk. Penelitian pengembangan ini dirancang dengan sebelumnya memperoleh suatu permasalahan untuk selanjutnya dibuat suatu pengembangan produk tertentu berdasarkan prosedur alur tertentu untuk mendapatkan hasil yang lebih baik dalam suatu kajian penelitian ilmu pengetahuan (Borg \& Gall, 1983) Dalam sigit purnama (2013). 
Instrumen pengumpulan data pada penelitian pengembangan multimedia interaktif yang peneliti gunakan observasi, wawancara, validasi prodak, Penilaian Test unjuk kerja Kemampuan Bermain Musik. Observasi berartikan suatu tindakan pencarian informasi sesuatu guna mencapai tujuan ulmiah tertentu Amir samsudin (2014). Observasi ini Dilakukan untuk mengetahui kondisi pembelajaran seni budaya dan prakarya bagaimana pembelajaran setelah menggunakan modul seni musik berbasis experiential learning. Sumber data pada observasi ini ada guru dan peserta didik setelah munggunakan pembelajaran konvensional kemudian pada saat pembelajaran menggunakan modul seni musik. Wawancara adalah salah satu cara mendapatkan informasi guna mendapat suatu makna pada topik ternetu Sugiyono (2016) Dalam Nunung Indah Pratiwi (2017).Wawancara ini bertujuan untuk mengetahui kondisi pembelajaran awal pembelajaran dan peserta didik dalam melihat bagaimana pembelajaran seni yang sudah berjalan. Sumber dari wawancara ini adalah guru dan siswa.

Validasi produk ini memiliki tujuan mengukur produk yang dikembangkan sudah dikatakan layak atau tidak untuk selanjutnya dapat diimplementasikan dilapangan dalam pembelajaran seni budaya dan prakarya.sumber data pada validasi produk ini adalah ahli yang sudah berkompeten. Penilaian tes unjuk kerja adalah suatu cara untuk melihat proses yang dilakukan anak. Rianti Januari (2014).Penilaian test untuk kerja ini bertujuan untuk mengukur tingkat kemampuan memainkan alat musik siswa berdasarkan pembelajaran. Sumber datanya adalah siswa.

\section{HASIL DAN PEMBAHASAN}

Hasil yang dikembangkan adalah produk modul pembelajaran seni music berbasis experiential learning pada pelajaran seni budaya dan prakarya.Tahapan yang digunakan dalam pengembangan ini menggunakan model borg and gall dengan 10 tahapan. Tahapan tersebut antara lain:

\section{Penelitian dan Pengumpulan Informasi}

Pada tahapan awal pembuatan modul seni musik ini adalah mengumpulkan informasi awal untuk mendapatkan analisis kebuthan,melihat kondisi pembelajaran yang dilakukan guru dengan menggunakan buku teks yang sudah ada untuk kemudian dianalisis kekurangan untuk akhirnya dibuat pengembangan suatu buku mahan ajar modul yang dapat dipakai dalam pembelajaran seni budaya dan prakarya dengan melakukan wawancara terhadap guru terkait pembelajaran musik yang telah dilakukan. Setelah memperoleh informasi, dari temuan yang didapat dijadikan xebagai acuan pembuatan modul pembelajaran.

\section{Perencanaan Pembuatan Modul Pembelajaran Seni Musik Berbasis Experiential Learning}

Pada tahapan ini setelah mendapat informasi dan masukan dari guru terkait pembelajaran seni, pembelajaran musik, selanjutnya dilakukan pembuatan desain buku yang akan dibuat dengan berbagai lieteratur yang mendukung dalam pembuatan modul ini yaitu tentang kemampuan bermain musik berlandaskan pembelajaran experiential learning.

\section{Pengembangan Modul Seni Musik Berbasis Pengalaman Experiential Learning}

\section{Penyusunan Modul}

Setelah mendapatkan literatur yang dibutuhkan untuk mendukung pembuatan modul,modul dibuat terlebih dahulu secara mandiri untuk kemudian meneyempurkanakan isi dari bagian-bagian materi yang diabahas secara detail yang selanjutnya akan dilakukan uji penilaian oleh ahli yang sudah berkompeten pada bidang terkait. Spesifikasi modul yang dikembangkan adalah sebagai berikut : (1) Materi yang disajikan sangat menyeluruh dari mulai dasar sampai praktik dalam materi pembelajaran musik. (2) Modul pembelajaran tentang pembelajaran 
kemampuan bermain musik. (3) Tahapan pembelajaran musik pada modul yang dibuat memadukan dan berkesinambungan dengan model pembelajaran experiential learning yang sangat baik untuk perkembangan anak. (4) Isi keseluruhan modul yang dibuat sangat menarik dari mulai sampul,peta kedudukan modul sampai daftar pustaka. (5) Isi keseluruhan modul yang dibuat (pengenalan pengetahuan dasar seni, kemampuan bermain musik, dan tahapan dalam pembelajaran secara experiential learning). (6) Modul pembelajaran yang dibuat akan dapat dijadikan sebagai buku acuan pembelajaran yang baru untuk siswa dan guru dalam pembelajaran kemampuan bermain musik.

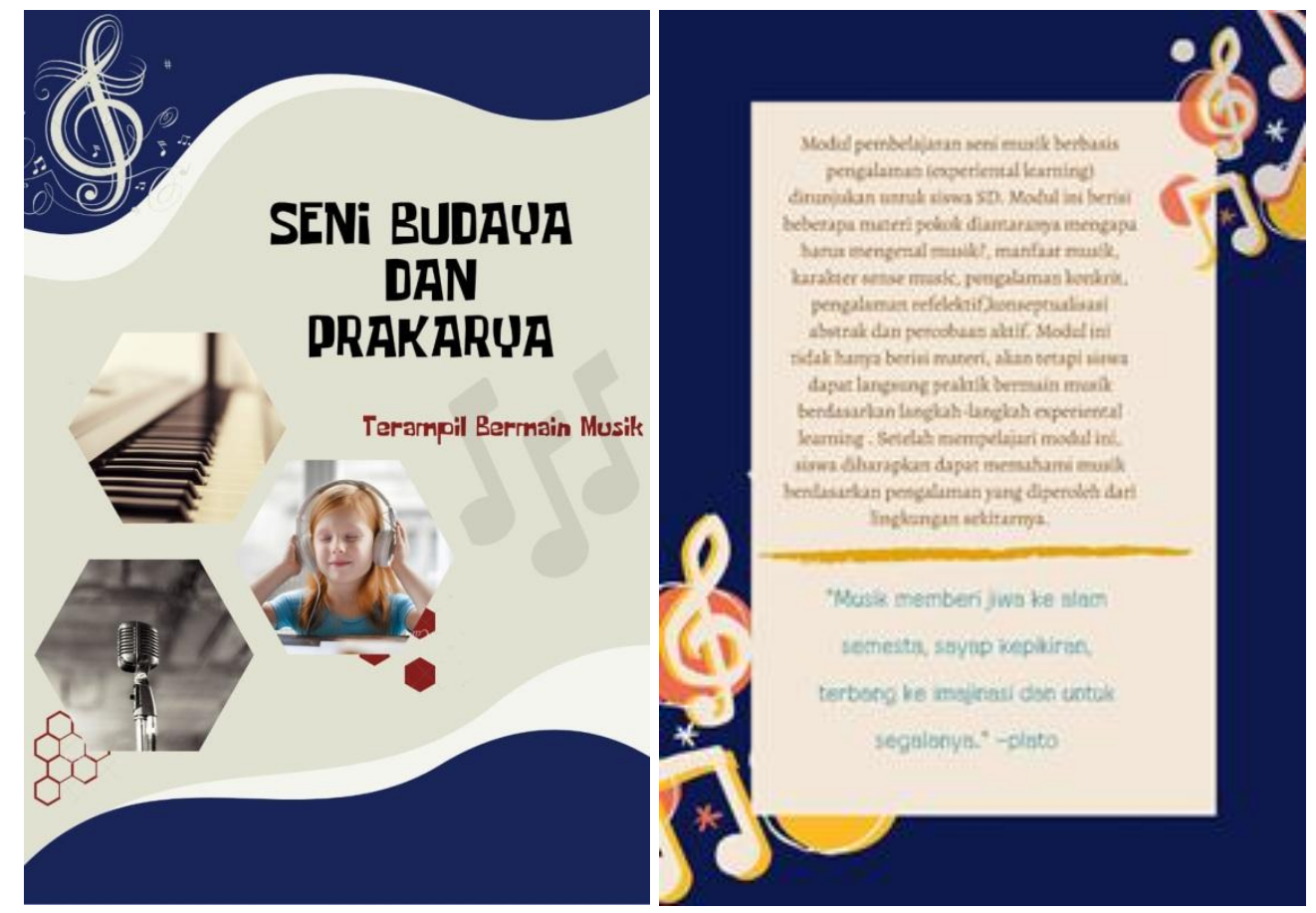

Gambar 1 Tampilan awal produk modul yang dikembangkan

\section{Penilaian Produk Ahli (Expert Judgement)}

Pada tahapan ini setelah modul selesai disempirnakan secara mandiri dilakukan uji kepada ahli, dalam penelitian ahli yang diminta untuk menilai produk sebelum revisi dosen yang ahli dalam bidang musik. Modul dilakukan uji apakah dapat dikatakan layak untuk kemudian dapat dipakai kepada peserta didik dalam pembelajaran.

\section{Uji Coba Terbatas terhadap Siswa}

Pada tahapan ini modul yang sudah mendapat kelayakan dari ahli dilakukan uji coba dengan terbatas kepada siswa untuk mengetahui kualitas dan hasil pembelajaran siswa dengan menggunkan modul kemampuan bermain musik yang dikembangkan. Uji coba terbatas ini dilakukan kepada 5 siswa.

\section{Penyempurnaan Produk Berdasarkan Respon Siswa}

Pada tahapan ini dilakukan penyempurnaan produk dari hasil uji coba siswa berupa modul pembelajaran kemampuan bermain musik yang mengacu pada model experiential learning Kemampuan bermain musik di sekolah.

\section{Uji Penggunaan Produk}

Setelah revisi modul seni musik berbasis experientl learning dilakukan berdasarkan penilaian dari para ahli, slanjutnya diuj icobakan pada lapangan utama. Subyeknya adalah siswa kelas VI SDN Nagreg 04 dan SDN Magung 03 yang berjumlah 46 siswa. Uji coba untuk mengetahui kelayakan modul yang sudah dikembangkan berkaitan dengan pengembangan modul 
seni musik berbasis experiental learning terhadap siswa kelas VI SD. Kemudian, dilihat kefektifan penggunaan modul seni musik melalui hasil belajar siswa melalui praktik bermain alat musik.

\section{Revisi Produk}

Setelah diujicobakan, modul seni musik tersebut selanjutnya direvisi berdasarkan ujicoba terbatas di lapangan, revisi dilakukan guna memperbaiki kekurangan yang terdapat dalam kedalaman isi dari modul atau dari penggunaan bahasa, selanjutnya tersusun produk berupa modul yang dikembangkan.

Hasil masukan revisi produk dari validator ahli sebagai validator kelayakan modul adalah sebagai berikut:(1) Memperbaiki struktur penelusian modul dengan memperbaiki kosa kata yang terjadi kesalahan penulisan(typo). (2) kedalaman materi yang ingin disajikan sangat mendalam mengenai subtansi materi-materi yang disajikan selanjutnya saran dari validator ahli memberi revisi judul pada modul dengan judul awal "terampil bermain musik" kurang dapat memaparkan kesalaman materi yang disajikan sehingga direvisi menjadi sense of music yaitu bagaimana musik dibahas mendalam terhadap makna-makna perkembangan psikologis pada anak dengan kombinasi berbasis experiential learning yaitu pembelajaran langsung dan mengedepankan makna didalam suatu pembelajaran. (3) Menambahkan Peta Kedudukan Modul,dari hasil pembahasan kedalaman setiap materi didalanya kurang menuangkannya kedalam sebuah peta kedudukan modul sehingga ringkasan materi apa saja yang akan disajikan pada modul dapat dilihat pada bagian awal.

\section{Revisi Produk Akhir}

Pada tahap ini dilakukan suatu penilaian layak tidaknya produk yang dikembangkan, dilakukan revisi setelah produk diuji coba revisi dilakukan agar produk yang dibuat dapat memiliki kualitas dan mutu yang baik untuk diterapkan pada pembelajaran selanjutnya.
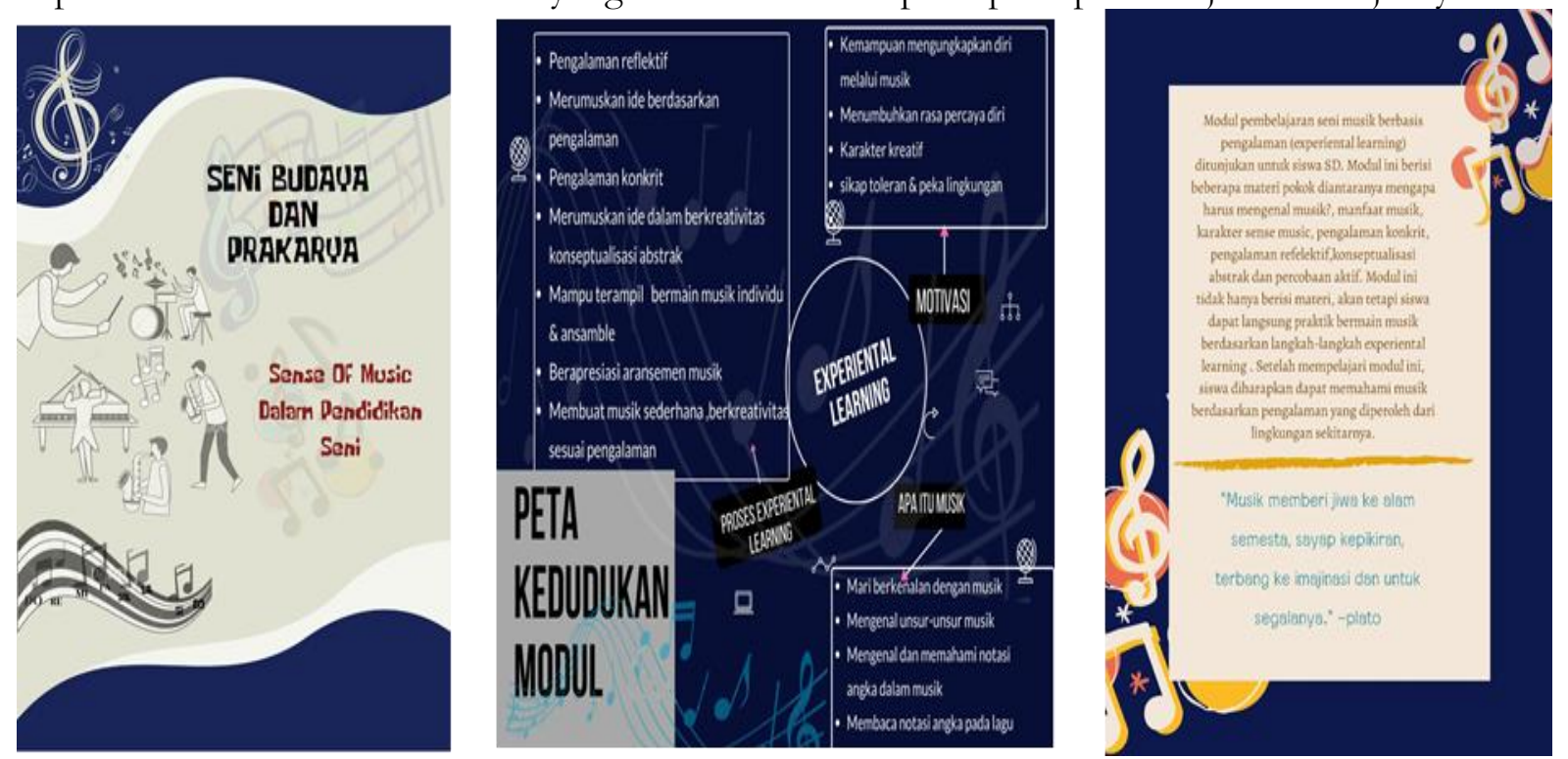

\section{Gambar 2 Hasil dari revisi produk akhir}

\section{Dissemination dan Implementation}

Pada tahapan ini produk yang sudah dinilai layak dan efektif diterapkan pada siswa sekolah dasar dilakukan.tahapan ini berupa menyebarkan produk yang telah dibuat kepada kalangan luas Diseminasi yang dipilih adalah melalui seminar dan publikasi jurnal internasional. Selanjutnya disebar luaskan ke sekolah SD di Kabupaten Bandung. Agar tahapan ini berjalan dengan baik dilakukan diskusi dengan pihak-pihak sekolah untuk mengangkat bagaimana pentingnya Modul seni musik berbasis Experiental Learning. 


\section{Tahap 1}

\section{Hasil Kebutuhan Modul Pembelajaran Seni Musik Berbasis (Experiential Learning) untuk Siswa SD Kelas VI.}

Berdasarkan analisis kebutuhan terhadap guru dan siswa. Analisis kebutuhan pengembangan tersebut dilakukan dengan observasi kebutuhan modul seni musik berbasis experiential learning oleh guru dan siswa. Hasil analisis kebutuhan menjadi acuan peneliti untuk mengembangkan modul seni musik berbasis experiential learning kelas tinggi di sekolah dasar. Adapun hasil analisis kebutuhan tersebut dapat dipaparkan sebagai berikut:

Kebutuhan menurut siswa terhadap pengembangan produk diperoleh dari analisis kebutuhan berupa observasi dan wawancara terstruktur oleh 23 siswa dari siswa kelas V1 SDN Nagreg 04. Analisis kebutuhan siswa terhadap modul seni musik berbasis experiential learning analisis awal melihat bagaimana kebutuhan terhadap pembelajaran seni budaya dan prakarya. Tujuannya dalam mengembangkan modul seni musik berbasis experiential learning kelas tinggi yang sesuai dengan kebutuhan terhadap siswa kelas VI.

\section{Tahap 2}

\section{Hasil Uji Kelayakan Modul Seni Musik Berbasis Experiential learning}

Setelah penyusunan modul seni musik berbasis experiental learning sselesai, kemudian dilakukan uji kelayakan kepada ahli media tujuannya untuk menilai layak tidaknya produk modul yang dikembangkan. Validitas dan revisi produk berupa data kuantitatif dan kualitatif. Modul Seni musik yang dikembangkan dalam peneliti ini divalidasi oleh tim ahli. Kegiatan validasi bertujuan untuk menggali saran, masukan dan penyempurnaan modul. Modul seni musik yang divalidasi berisi tentang materi seni musik kelas VI disekolah dasar. Ahli yang memvalidasi modul seni musik berbasis experietal learning yang dikembangkan terdiri atas pakar-pakar di bidangnya. Validasi model seni musik berbasis experiantal learning pada penelitian ini telah dilakukan oleh ahli yaitu bapak Dr.Ludy Hermawan M.Pd Ibu Siti Fatimah S.Sn, M.Sn praktisis dan dosen seni musik kemudian oleh Ibu Nuri Anisa M.Pd, dan Bapak Imam Ma'arif M.Pd, Fokus validasi terletak pada kelayakan isi,kebahasaan, penyajian, dan kegrafikan.Hasil validasi memperlihatkan bahwa modul seni musik berbasis experiental learning hasil pengembangan dapat dipergunakan dengan revisi kecil dengan berjategori layak digunakan hal ini senada senada dengan P. A. Sembodo. (2015) peningkatan kemampuan siswa dalam melatih keterampilan motorik dalam melatih keranak permainan alat musik salah satunya dapat dibuatkan nya pembelajaran khusus yaitu dengan membuat buku atau modul pembelajaran khusus disertai tahapan-tahapan pembelajaran yang mudah dipahami siswa. Revisi pada modul seni musik berbasis experiental learning diantaranya memperbaiki kalimat-kalimat yang salah ketik, perbaikan kalimat dan tata bahasa sehingga menjadi lebih efektif. menganalisis materi pada modul sehingga tidak terdapat kesalahan konsep, serta penyajian modul yang disesuaikan dengan kebutuhan siswa. Modul yang telah dilakukan revisi ditinjau kembali sehingga hasil validasi memeroleh kategori sangat valid dan dapat digunakan pada tahapan selanjutnya.

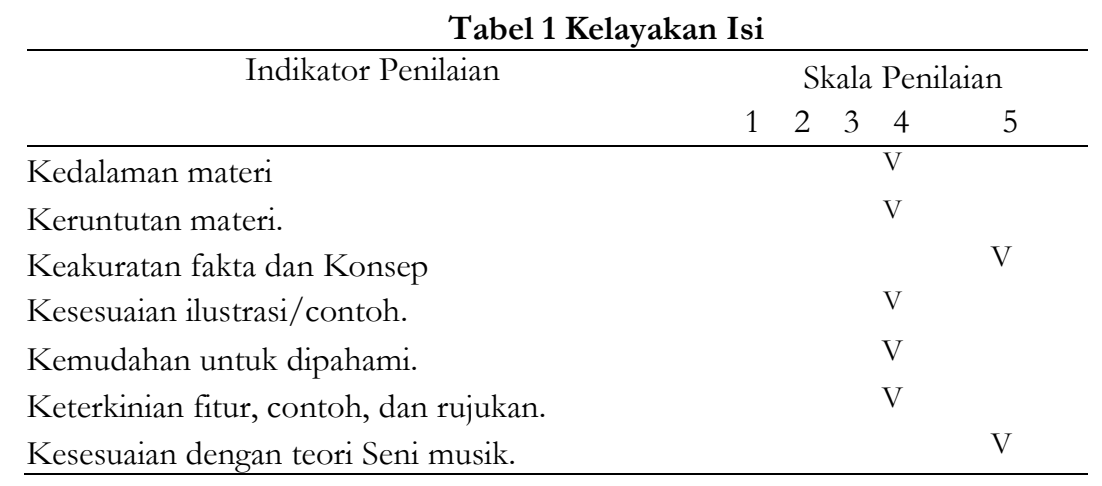


Tabel 2 Kelayakan Bahasa

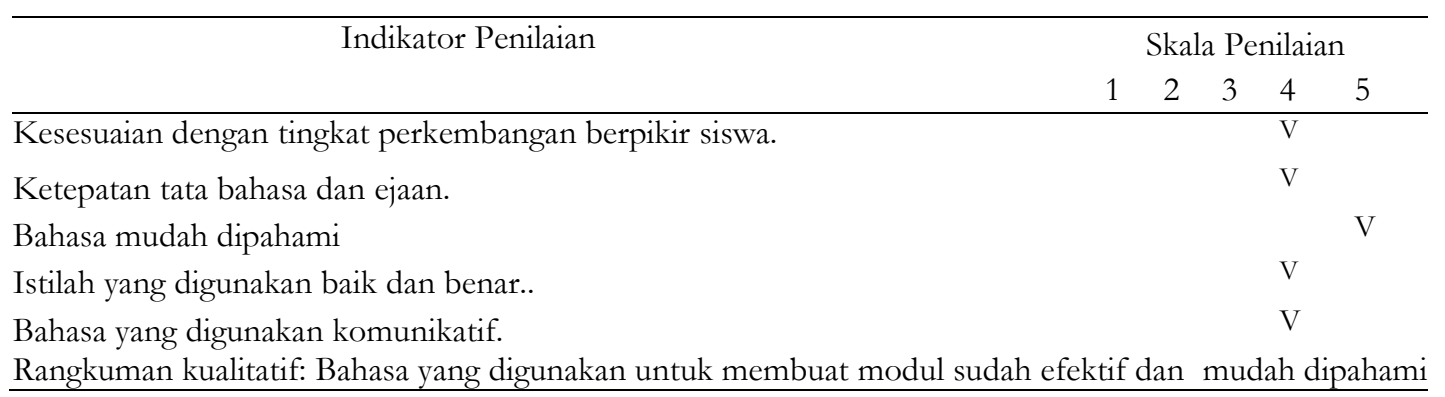

Tabel 3 Kelayakan Penyajian

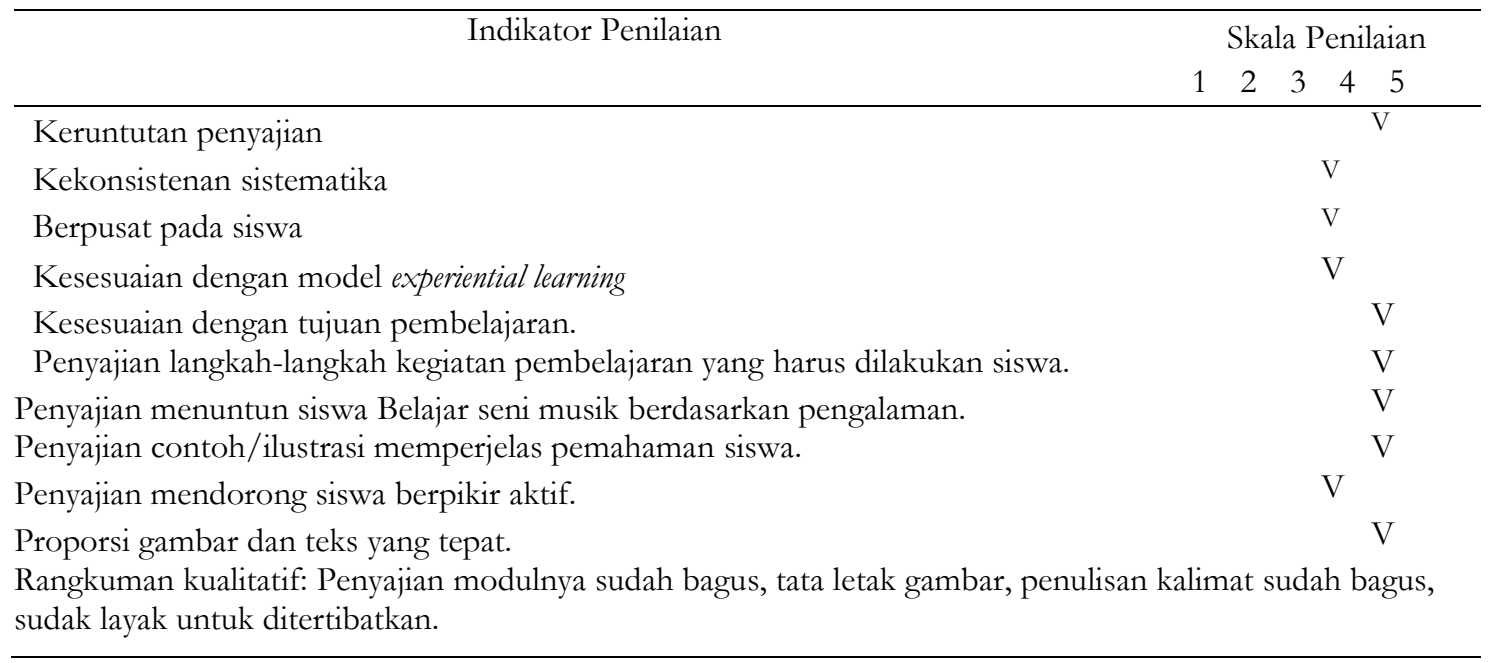

Tabel 4 Kelayakan Kegrafikan

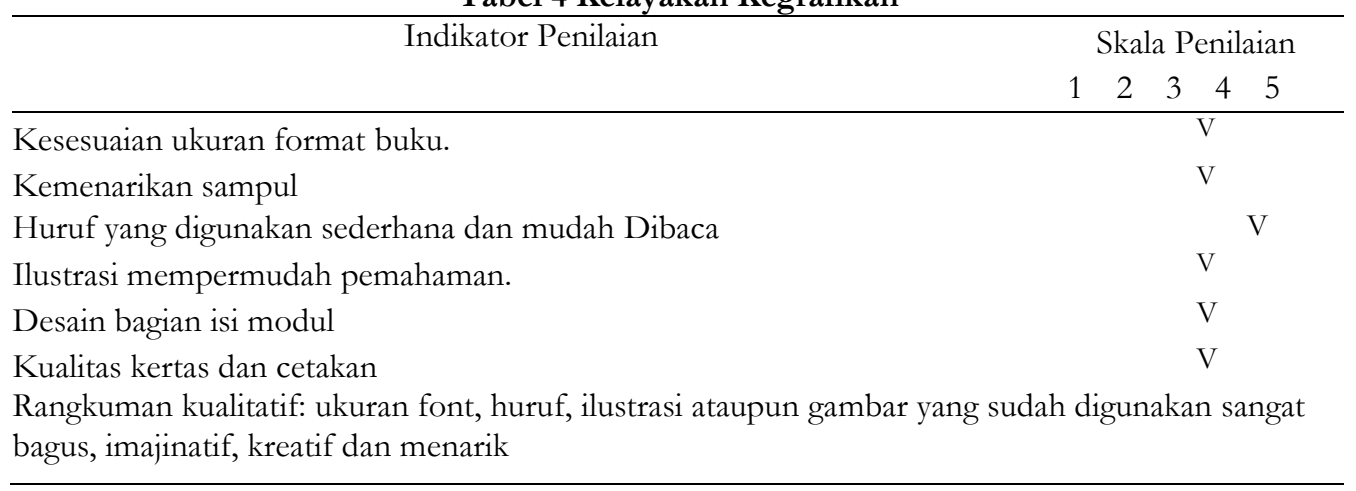

Secara keseluruhan modul ini sudah layak untuk digunakan oleh peneliti sebagai salah satu instrumen dalam penelitian yang dijalani. 
Tabel 5 Saran Validator Ahli

\begin{tabular}{ll}
\hline Nama & Saran \\
\hline Siti Fatimah, S.Sn. M.Sn & Bentuk materi yang disajikan sudah \\
& meliputi sesuai dengan tema konsep yang \\
& diambil tetapi ada sedikit penjelasan materi \\
& yang harus diperjelas \\
- & Bahasa yang digunakan untuk membuat \\
& modul sudah efektif dan mudah dipahami \\
& siswa SD tetapi masih ada kesalahan ketik \\
& yang harus diperbaiki \\
- & Penyajian modulnya sudah bagus, tata letak \\
& gambar, penulisan kalimat sudah bagus \\
& tetapi harus diperbaiki kesalahan penulisan, \\
& sudak layak untuk ditertibatkan. \\
- & Dari sisi kelayakan isi sudah cukup baik, \\
& hanya daam penyajian masih terdapat \\
& beberapa kekeliruan dalam penggunaan \\
& bahasa. Perhatikan dalam pengambilan \\
& rujukan, cara penulisan rujukan dan \\
& penulisan referensi harus diperhatikan \\
- & Pada tata bahasa, lebih diperhatikan lagi \\
& kata-kata yang "salah ketik/ typo" \\
Konsitenkan apakah experiential learning atan \\
Nuri Annisa, S.Pd, M.Pd \\
experiental learning Perhatikan kaidah \\
penulisan secara keseluruhan menurut EBI \\
Secara keseluruhan, baik secara kelayakan \\
isi, kelayakan penyajian, kelayakan bahasa \\
dan kelayakan kegrafikan sudah cukup \\
bagus namun harus lebih diperhatikan lagi \\
pada tata penulisan dan tata bahasa. \\
- Secara keseluruhan sudah sangat baik dan \\
layak diberikan sebagai sumber belajar baru \\
tetapi harus diperhatikan dalam penulisan \\
kata masih terdapat kesalahan ketik (typo) \\
Dalam penyajian materi gambar desain \\
modul secara keseluruhan sudah sangat \\
baik dan bagus hanya ada masukan sedikit \\
diperhatikan dalam pemilihan kosa kata ada \\
yang harus diperbaiki dengan melihat \\
perkembangan pemahaman siswa anak SD. \\
Bahasanya aga dipermudah lagi \\
\hline
\end{tabular}

Berdasarkan saran dari validator tersebut, maka peneliti melakukuan revisi sebagai berikut: (1) Memperbaiki struktur penelusian modul dengan memperbaiki kosa kata yang terjadi kesalahan penulisan(typo) (2) Memperbaiki struktur tata bahasa yang disesuaikan dengan tingkat pemahaman tingkat Sekolah Dasar. (3) Lebih memperjelas pendalaman materi dengan tingkat pemahaman siswa sekolah dasar agar mampu lebih mudah dipahami sebagai sumber belajar. 


\section{Tahap 3}

\section{Uji Coba Terbatas}

Uji coba terbatas dilakukan pada 5 siswa kelas 5 SDN 04 Nagreg. Dari 5 Siswa tersebut, peneliti melakukan observasi aktivitas siswa menggunakan modul seni musik berbasis experiental learning diperoleh skor 88,90 dengan kategori sangat antusias. Kemudian dalam melakukan unjuk kerja bermain musik, Peningkatan rata-rata $\mathrm{N}$-gain adalah 0,34 dengan kategori sedang, maka modul seni musik berbasis experiental learning terhadap peningkatan seni budaya dan prakarya peserta didik disekolah dasar dapat digunakan dalam pembelajaran Seni budaya dan prakarya di kelas tinggi.

\section{Uji Coba Lapangan}

Kelas kontrol yang peneliti gunakan adalah kelas 6 SDN Magung 03 yang berjumlah 23 siswa. Kelas kontrol dilaksanakan pembelajaran seni musik seperti biasa tanpa menggunakan modul berbasis experiental learning. Dari hasil unjuk kerja keterampilan bermain musik (dapat dilihat dilampiran) Berdasarkan hasil tabel unjuk kerja, maka diperoleh rata-rata ,7. Kemudian selanjutnya menghitung simpangan baku dari kelas kontrol. Diperoleh nilai varian (s2) 415,4 dan simpangan baku (s) 20,3.

Berdasarkan hasil yang diperoleh unjuk kerja yang dapat lihat pada lampiran, maka diperoleh rata-rata 51,3. Kemudian selanjutnya menghitung simpangan baku dari kelas kontrol. Diperoleh nilai varian (s2) 300,12 dan simpangan baku (s) 17,2.

\section{Kelas Eksperimen}

Pada kelas eksperimen diberikan tindakan berupa pembelajaran seni musik menggunakan modul seni musik berbasis experiental learning. Kelas eksperimen adalah kelas 6 SDN 04 Nagreg yang jumlah 23 siswa. Peneliti melakukan observasi siswa dalam pembelajaran seni budaya dan prakarya menggunakan modul seni musik berbasis experiental learning dengan aspek sebagai berikut: (1) Sikap antusias siswa terhadap modul seni musik berbasis experiental learning. (2) Rasa ingin tahu siswa tentang pembelejaran seni musik. (3) Minat untuk menggunakan dan bermain alat musik. (4) Siswa mampu menggunakan dan mempraktekan alat musik melalui modul yang dibuat. Hasil observasi pembelajaran dipaparkan pada tabel di bawah ini (dapat dilihat dilampiran).

Berdasarkan hasil observasi pembelajaran menggunakan modul seni musik berbasis experiental learning, diperoleh hasil bahwa rata-rata pembelajaran mencapai 95,65\% dengan rincian per aspek sebagai berikut: Keantusiasan siswa terhadap modul seni musik berbasis experiental learning diperoleh hasil bahwa 100\% siswa sangat antusias dengan modul seni musik berbasis experiental learning. Hasil analisis rasa ingin tahu siswa tentang modul seni musik berbasis experiental learning. Berdasarkan hasil yang diperoleh rata-rata rasa ingin tahu siswa terhadap modul seni musik 100\%. Analisis selanjutnya adalah minat siswa terhadap modul seni musik berbasis experiental learning tersebut dipaparkan berdasarkan hasil observasi minat siswa terhadap modul seni musik berbasis experiental learning hasil bahwa 100\% siswa sangat berminat terhadap modul seni musik berbasis experiental learning. Aspek selanjutnya adalah Hasil analisis kemampuan siswa modul seni musik berbasis experiental learning.Berdasarkan hasil yang diperoleh hasil analisis bahwa 11 siswa mampu menggunakan menggunakan alat musik dengan belajar menggunakan modul seni musik berbasis experiental learning dengan persentase 47,8\% dan 12 siswa kurang mampu menggunakan menggunakan alat musik dengan belajar menggunakan modul seni musik berbasis experiental learning dengan persentase 52,2\%.

Hasil Unjuk kerja kemampuan bermain musik pada keadaan awal (pra-test) pada kelas eksperimen dilakukan belum menggunakan modul seni musik memperoleh hasil Rata-rata unjuk kerja kemampuan siswa dengan menggunakan buku teks yang telah ada memperoleh hasil 49,89. 
Kemudian kelas eksperimen diberikan media modul seni musik berbasis experiental learning dengan hasil unjuk kerja Uji $\mathrm{T}$ dilakukan untuk menelaah apakah ada perbedaan atau tidak antara kemampuan awal (pretest) dan kemampuan akhir (posttest) kemampuan bermain musik asiswa kelas eksperimen. Uji t dilakukan dengan menggunakan uji Paired Samples T-Test. Hasil perhitungan hasil output SPSS uji perbedaan rata-rata data pretest dan posttest peningkatan kemampuan bermain musik peserta didik hasil rangkuman data dapat disajikan pada Tabel 6.

Tabel 6 Uji Paired Samples T-Test Data Pretest dan Posttes Keterampilan Bermain Musik Kelas Eksperimen

\begin{tabular}{rcc}
\hline & \multicolumn{2}{c}{ Paired Sampel Test } \\
T & Df & $\begin{array}{c}\text { Sig. (2- } \\
\text { tailed) }\end{array}$ \\
9 & & 0,000 \\
4.296 & 23 & \\
\hline
\end{tabular}

Berdasarkan Tabel.2, berikut adalah langkah-langkah pengambilan keputusan untuk uji Paired Samples T-Test.

Taraf signifikansi $\alpha=5 \%(0,05)$

$$
\begin{aligned}
& \text { Hipotesis Uji } \\
& H_{0}: \mu_{1}=\mu_{2} \\
& H_{1}: \mu_{1} \neq \mu_{2}
\end{aligned}
$$

Dimana:

$\mathrm{H}_{\mathrm{o}}$ : Tidak terdapat perbedaan yang signifikan antara rata-rata kemampuan awal (pretest) dan kemampuan akhir (posttest) kemampuan bermain musik siswa kelas eksperimen.

$\mathrm{H}_{1}$ : Terdapat perbedaan yang signifikan antara rata-rata kemampuan awal (pretest) dan kemampuan akhir (posttest) kemampuan bermain musik siswa kelas eksperimen.

$\mu_{1}$ : Rata-rata kemampuan awal (pretest) kemampuan bermain musik siswa pada kelas eksperimen

$\mu_{2}$ : Rata-rata kemampuan akhir (posttest) kemampuan bermain musik e siswa pada kelas eksperimen.

Kriteria Uji

$\mathrm{H}_{\mathrm{o}}$ diterima: jika nilai signifikansi (Sig.) $\geq \alpha(0,05)$

$\mathrm{H}_{\mathrm{o}}$ ditolak: jika nilai signifikansi (Sig.) $<\alpha(0,05)$

Berdasarkan tabel di atas dapat diketahui bahwa nilai signifikan sig. (2-failed) untuk skor nilai pretest dan posttest kemampuan bermain musik siswa pada kelas eksperimen adalah 0,000 , karena nilai sig. $0,000<\alpha(0,05)$ maka maka Ho ditolak. Artinya, terdapat perbedaan yang signifikan antara rata-rata kemampuan awal (pretest) dan kemampuan akhir (posttest) kemampuan bermain musik eksperimen pada taraf signifikansi $\alpha=5 \%(0,05)$. Dari hasil perolehan tersebut dapat di tarik kesimpulan yaitu dari data yang diperoleh menunjukan terdapat perbedaan rata-rata peningkatan kemampuan bermain musik peserta didik yang sebelum menggunakan modul seni musik berbasis Experential Learning dengan yang sudah menggunakan modul seni musik berbasis Experential Learning hasil rata-rata peningkatan kemampuan bermain musik peserta didik sebelum diberi perlakuan menggunakan modul seni musik berbasis Experential Learning lebih rendah dibandingkan dengan hasil rata-rata peningkatan kemampuan bermain musik peserta didik yang diperoleh setelah diberikan perlakuan menggunakan modul seni musik berbasis Experential Learning. 
Kemudian setelah menghitung Rata-rata kelas eksperimen setelah menggunakan media modul seni musik berbasis experiental learning adalah 78,98. kemudian menghitung standart deviasi dengan nilai varian (s2) 205,93 dengan nilai deviasi (s) 14,3. selanjutnya juga menghitung $\mathrm{N}$-gain dengan membandingkan rata-rata unjuk kerja pre-test dan post-test. Hasil penghitungan diperoleh hasil $\mathrm{g}=0,51$ dengan kategori sedang. Kemudian selanjutnya menghitung simpangan baku (S2) dari standart deviasi kelas kontrol dan kelas eksperimen sehingga diperoleh hasil 303,94. Kemudian selanjutnya menghitung thitung. Penghitungan thitung diperoleh hasil 6,8. Kemudian membandingkan dengan ttabel. Jumlah kelas kontrol (n1) dan kelas eksperimen (n2) adalah 48, maka $(\mathrm{n} 1+\mathrm{n} 2)-2=46$. Taraf signifikan $\mathrm{a}=5 \%$, maka ttabel adalah 1,67. Maka thitung $>$ ttabel. Hasil desiminasi yang telah dilakukan pertama adalah melakukan penyebaran melalui seminar tingkat internasional hasilnya produk yang dikembangkan mendapat penilaian baik tentang pentingnya pengembangan pembelajaran seni musik disekolah dasar kemudian selanjutnya menyebarkan produk di beberapa sekolah dasar kabupaten bandung Agar tahapan ini berjalan dengan baik dilakukan diskusi dengan pihak-pihak sekolah untuk mengangkat bagaimana pentingnya Modul seni musik berbasis Experiental Learning pada mata pelajaran seni budaya dan prakarya disekolah dasar hasilnya pengembangan modul yang dibuat mendapat respond an penilaian baik tentang baiknya pengembangan pembelajaran seni music ditingkat sekolah dasar.

\section{KESIMPULAN}

Kesimpulan pada penelitian ini Pembelajaran seni budaya dan prakarya membutuhkan media modul yang khusus yang didalamnya mencakup pembelajaran dasar berserta tahapantahapan pembelajarannya secara terperinci maka dari itu dibuatlah pengembangan modul seni musik berbasis experiental learning. Kemudian Setelah dibuat modul yang disusun secara terperinci dari setiap materi, dilakukan validasi untuk mengukur kelayakan modul seni musik berbasis experiental learning oleh ahli yaitu ahli pada bidang seni musk,ahli media pembelajaran,dan ahli tata kebahasaan. Hasil kelayakan dari semua ahli memperoleh hasil 87,5 dengan kategori valid,dengan kata lain modul seni musik berbasis experiential learning layak digunakan Dari uji efektifitas, diperoleh hasil $\mathrm{N}$-gain adalah 0,4 dengan kategori sedang. Sedangkan penghitungan nilai $\mathrm{t}_{\text {hitung }} 6,9$ $>t_{\text {tabel }}$ 1,67 sehingga modul pembelajaran seni music berbasis experiential learning efektif digunakan dalam pembelajaran.

\section{REFERENSI}

Alves, C., \& Putnik, G. (2019). Experiential learning of CAD systems interoperability in social network-based education. Procedia CIRP, 84, 209-214. https://doi.org/10.1016/j.procir.2019.07.002

Ata Aktürk, A., Demircan, H. özlen, Şenyurt, E., \& Çetin, M. (2017). Turkish early childhood education curriculum from the perspective of STEM education: A document analysis. Journal of Turkish Science Education, 14(4), 16-34. https://doi.org/10.12973/tused.10210a

Firrincieli, A. (2017). Maieutic: A Teaching and Learning Approach. As Applied to Western Music. Procedia - Social and Behavioral Sciences, 237(June 2016), 1520-1525. https://doi.org/10.1016/j.sbspro.2017.02.239

Leal-Rodríguez, A. L., \& Albort-Morant, G. (2019). Promoting innovative experiential learning practices to improve academic performance: Empirical evidence from a Spanish Business School. Journal of Innovation and Knowledge, 4(2), 97-103. https://doi.org/10.1016/j.jik.2017.12.001 
Mareza, L. (2017). Cultural Art And Craft Education As A General Intervention Strategy For Special Needs Children. Scholaria, 7(1), 35-38.

Pratiwi, N. I. (2017). Penggunaan Media Video Call dalam Teknologi Komunikasi. Jurnal Ilmiah Dinamika Sosial, 1(2), 202-224.

Purnama, S. (2016). Metode Penelitian Dan Pengembangan (Pengenalan Untuk Mengembangkan Produk Pembelajaran Bahasa Arab). LITERASI (Jurnal Ilmu Pendidikan), 4(1), 19. https://doi.org/10.21927/literasi.2013.4(1).19-32

Rauduvaite, A., \& Lasauskiene, J. (2015). Music Education: Some Aspects of Pedagogical Efficiency of Popular Music Integration. Procedia - Social and Behavioral Sciences, 197(February), 910-915. https://doi.org/10.1016/j.sbspro.2015.07.27

Roffiq, A., Qiram, I., \& Rubiono, G. (2017). Media Musik Dan Lagu Pada Proses Pembelajaran. JPDI Jurnal Pendidikan Dasar Indonesia), 2(2), 35. https://doi.org/10.26737/jpdi.v2i2.330

Rohman, A. A., Suryawan, A. I., \& Priyanto, I. J. (2019). Penerapan Model Experiential Learning Berbantuan Media Gambar Untuk Meningkatkan Kreativitas Kerajinan Tangan Peserta Didik. $\quad$ Educare, 17(2), 119-126. http://jurnal.fkip.unla.ac.id/index.php/educare/article/view/251

Ruokonen, I., Pollari, S., Kaikkonen, M., \& Ruismäki, H. (2012). The Resonaari Special Music Centre as the Developer of Special Music Education between 1995-2010. Procedia Social and Behavioral Sciences, 45, 401-406. https://doi.org/10.1016/j.sbspro.2012.06.576

Sukandar, A. K., \& Astika, I. W. (2020). Upaya Meningkatkan Kemampuan Bermain Alat Musik Anak dengan Pembelajaran Berbasis Kreativitas (Improving Children's Musical Ability through Creativity Learning ). 2(5), 805-814.

Syamsudin, A. (2015). Pengembangan Instrumen Evaluasi Non Tes (Informal) untuk Menjaring Data Kualitatif Perkembangan Anak Usia Dini. In Jurnal Pendidikan Anak (Vol. 3, Issue 1). https://doi.org/10.21831/jpa.v3i1.2882

YETTI, E., \& KHAIRIAH, I. (2017). Peningkatan Kemampuan Musikalitas Melalui Bermain Alat Musik Dol. JPUD - Jurnal Pendidikan Usia Dini, 11(2), 226-237. https://doi.org/10.21009/jpud.112.03

(Alves \& Putnik, 2019; Ata Aktürk et al., 2017; Firrincieli, 2017; Leal-Rodríguez \& AlbortMorant, 2019; Mareza, 2017; Pratiwi, 2017; Purnama, 2016; Rauduvaite \& Lasauskiene, 2015; Roffiq et al., 2017; Rohman et al., 2019; Ruokonen et al., 2012; Sukandar \& Astika, 2020; Syamsudin, 2015; YETTI \& KHAIRIAH, 2017) 